\title{
Study on Influences of Screen Culture on Developing Modern College Students' Values
}

\author{
Cong Huang \\ School of Marxism \\ Wuhan University of Science and Technology \\ Wuhan, China 430000
}

\begin{abstract}
Screen culture is a new culture rising with the development of TV and film industries, having features of being general, visual, guiding and amusing. In the meantime, screen culture is in a close connection with college students, impacting the formation of students' values. Screen culture is a public thing carrying social value, and the screen culture in market economy is a main part factored in forming students' values, so it has been an important necessity to lead and set up students' values through strengthening the leading role of screen culture in the construction of socialist core value system, setting screen culture appreciation course in colleges and making full use of public film ads enable students to cultivate senses of social responsibilities.
\end{abstract}

Keywords—screen culture; college students; values

\section{INTRODUCTION}

Nowadays, screen culture has been a necessity in daily activities, for example, films and TV plays have become necessary parts for the people, and especially it is much easier for college students to access to all kinds of screen culture works such as micro films and online videos at the time of new media. Based on analyzing concepts of screen culture and its influence on students developing values, this article deeply disclose relations between the two.

\section{DEFINITIONS OF THE SCREEN CULTURE}

\section{A. Screen Culture}

When a short film Arrival of $A$ Train at the Station was shown by Lumiere Brothers in 1896, some audients were much scared to run away when watching the coming train. Up to now, the shock that the people felt before the first film has disappeared completely, and films and TVs have been a necessity for everyone as public media, influencing what the people think, do and want. Accordingly the new culture under the influences of films and TVs is called screen culture. Specifically, screen culture means that relying on modern technologies, carries such as TVs, films and online videos are used to integrate music, painting, literature, aesthetics, sociology and communication, which have artistic appeal beyond restrictions in territory and culture to transmit information and thought. As art, screen culture, gathering advantages of diverse arts formed in history, is all-inclusive, simple and straightaway so as to meet what the people need aesthetics. As a tool for transmission, screen culture contains abundant information visual and audible, popular in the public and rapid to go around, which gradually replaces traditional paper media, becoming one of the most significant public media in the society. As cultural form, screen culture discloses social and cultural phenomena of a country, region and people in a time, which also bring influence to all the social fields such as politics, economy, and culture, etc. Nowadays, for college students, the worlds in films and TVs are extension of real world, which meet their thirst of understanding the world and influence their cognition and behaviors in real world.

\section{B. Characteristics of Screen Culture}

First, visual, relying on pictures and sounds, film and TVs works produce direct, vivid and multiple influences on two human sensor organs - eyes and ears, which work to spread information, record events and reflect real things, and the audiences may have real recognition and feeling through them. Especially pictures play an apparent role. First all, pictures themselves are information carriers, generally a picture may contain a lot of information that audiences can get; second, compared to dull letter information, pictures are easy to understand and appreciable and easy to attract eyeballs of the audiences. At last, the visual shocks unable to be expressed may great impress on those who get the information, transmitting information efficiently. At present, short videos and documentaries are used in politics teaching by teachers to teach students in class just because of its being visual, which make it easier for students to get and master key knowledge. Second, widespread, it means that screen culture has a great number of audiences, the information carriers ranging from newspaper, books and TVs and films have changes, besides, the threshold to get information is lowered as well. Traditionally, if a person is uneducated, illiterate or poorly educated, it will be uneasy for him or her to get efficient information. However, relying on TVs and films, he or she can watch and listen. On the one hand, the information that the latter shows is much clearer and direct; On the other hand, guided by markets, the more the audients are the more the economic benefits are, which determines that TV and film works are required to meet audiences with diverse cultural background, making it easy to understand and acceptable. Therefore, the audiences who may differ in age and cultural background can sit before TVs together in 
order for get information, release and so on, the Spring Festival gala every year can prove it well. Third, amusing. The deep love to TVs and films by audients mainly depends on its being amusing. Neil Postman, an American scholar showed in his works Amusing Ourselves to Death "Amusement is a form beyond mentality for all utterances on $\mathrm{TV}$, whatever the contents are, whatever the perspectives are, All on TV are just to amuse us". In modern society, everyone suffers high pressure in life and work in a rapid rhythm, generally watching TV is to see something pleasing and comfortable to relax. The amusing screen culture just hits the point, which can relax the people, making them free and good. Many students like watching comedies like Love Apartment and varieties like Happy Camp, though the programs contain no profound connotation or edutainment, yet the humorous dialogues and exaggerated and funny body languages can make all laugh, meeting the needs of college students to relieve the pressure in study. It is true that some programs have integrated amusement and education such as Dad, Where Are We Going, a reality show with extremely high audience rating, where the awkward dads and children tickle audiences and enlighten our thoughts of children education and affections, the programs are what we have been advocating. Forth, guiding, seen from the transmission effect, screen culture is not only amusing but also guiding, because, on the one hand, TV and film works are created to pass some information, which reflect what the creators like or dislike, showing a judgment on whether a thing is right or wrong; On the other hand, just because of being visual, widespread and amusing, the audiences, when receiving the information from screen culture, will almost give additional personal thought, and not feel dull, as a result, the screen culture is potentially influencing the people on how to think, judge and act. Especially college students, being main audiences for screen culture, are apparently influenced. For example, mainstream films may improve college students' political vulnerability, playing a role of promoting patriotism, collectivism and advocating hardship, simplicity and diligence and so on; the Chinese Characters Dictation Competition held by CCTV can guide college students return to writing from typing, getting started to value Chinese characters writing. Hence, whatever the audiences watch such as homemade films, imported ones, TV plays or variety shows, even news or ads, all are playing a leading and model role for the people potentially.

\section{ANALYZING THE INFLUENCES OF SCREEN CULTURE on DEVELOPING COLLEGE STUdents' IN VALUES}

Nowadays, screen culture is a part of daily life for college students, which, just like an invisible hand, applies double influences on students' values. When doing good, it can help those who are confused to establish sublime ideal and seek a correct way for life; when doing bad, it may dissolve the correct values that colleges and families transmit, causing students to go off the correct path.

Currently, watching TVs and films has become a most popular and general amusement for college students. In spare times, most like to surf online, downloading or watching TV plays, films or variety shows that they like. According to the
Survey Report of Chinese Audiences from 2014 to 2015 released by Entgroup, with regard to the most popular channels for watching films, $77.3 \%$ turned to online. And most who watch films in cinemas were college students. Likewise, the data from Entgroup show, young people aged 20-29 are main audiences in cinemas, amount to $37.3 \%$ of the total. Main reasons for conditions are given as follows, on the one hand, it needs lower costs to watch films, and college students have more free time to do that; on the other hand, the screen culture market is expanding and there are abundant resources related to screen culture. Take the film market as an example, starting from 2003 when Chinese film reform got started, the film market scale in China has been increasing stably by about $30 \%$. According to the statistic data of Chinese film markets in 2013 released by Administration Center of Digital Film Content, SAPPRFT, there were 5,077 projection screens newly added across the country in 2013, average 14 added per day, and the total of project screened was 18,195 in the country. Yet there were about 1,500 projection screens across the country in 2002, which reached 4,200 in 2008 and 9,200 in 2011, doubled in recent two years at a speed of explosive increase; and the audiences in city exceeded 0.6 billion, with 0.61 billion film tickets sold, 0.15 billion increased compared to previous year; and the annual box office income first broke 20 billion yuan, reaching 21.769 billion yuan, increased by $27.51 \%$, and it took only three years to achieve the income increased from 10 billion to 20 billion. In 2013, Chinese films performed well, and the box office income of Chinese films totaled 12.5 billion yuan, amount to $58 \%$ of the total, among 59 films with box office income exceeding 100 million yuan, 32 were Chinese films; on the first day of New Year 2014, the box office income totaled 226 million yuan across the country, breaking the single day box office record of 190 million yuan on Valentine's Day of previous year. At the beginning of 2013, China became the second largest market around the world, next only to the USA, account to $10 \%$ of global box office income, which was $7.8 \%$ in 2012 ; some films which targeted college students earned a lot, three films including So Young, American Dreams in China and Tiny Times, which featured youth and campus, ranked top ten in annual box office income and ever became hot issues among college students. There are all kinds of film resources online and easy to access to, which are one of the main channels for college students to get screen culture. Seen from the above, screen culture and students' lives are closely connected, besides, with extreme abundant film resources and huge influences of screen culture, whether college students actively watch or get film works or get no access to them, the information will still spread or penetrate in the social and cultural lives through social interactions, and the whole group of college students will be coved.

\section{INFLUENCES OF SCREEN CULTURE ON DEVELOPING College Students' Values}

\section{A. Active Influence}

Set active and progressive values of life, the values of life is defined as basic concepts that the people hold to recognize and evaluate their social position, life goal, significance, 
attitude as well as relations between individuals and social collectives, people and people, which predominate the overall goal of values of life. College students are young, having little social experience, who generally are in lack of deep understanding and inexperienced in life goal, significance and so on. Film works may break boundaries in time, space and experience, showing the growing path of different persons with a period or life through a short time episode, and it's unnecessary for college students to endure such experience to get rich life experience. Besides, directors and scriptwriters may show values of their own through epitasis and character ending arrangement, providing correct instruction to students potentially and enable them set active and progressive values of life. The differences in life goal and significance recognition will promote the differences in decision making on the public, private, obligations and benefits to be faced. The active roles of screen culture on students' values of life mainly include: first, help college students make sure of correct life orientation and values. Rudy in the film Rudy Expanded Score was physically well and common in gift, playing as ladder player and alternate at University of Notre Dame rugby team, never having a chance to enter the court, in addition, he had to endure the difficulties from coaches and cynicism from teammates. However, he refused to take his face lying down, keeping optimistic and training with full enthusiasm every day. Finally all of the others were moved by him and he was included in the team in the last competition before graduation, defeating its opponent. Through the film, college students are expected to say no to passivism or decadence when suffering frustration and failure in life, and keep tireless and struggle for ideals with whole heart and soul, setting a lofty and selfless moral values. College students are the future of the people, whose morality is directly related to the inheritance and development of traditional Chinese virtue as well as stability of social order. Rejecting abstract and dull morality preaching, screen culture shows a string a fresh cases before college students, disclosing justly and assailing vile practices in the society, digging up and praising the facts such as family affection, friendship and love, and all are shown from the bottom of heart and reasonably, through such films, students will be promoted in morality and feel the deposits of morality. Most films directed by director Xie Jin dare to face history and reality, which carry his deep thought of social problems and ethics and morality. Speaking of motives for film production, he said, the films shall not only enable audiences to enjoy aesthetics and distinguish ugliness, but also intensify and improve moral concepts of the people. His films such as Legend of Tianyun Mountain, Herdsman, Wreaths at the Foot of the Mountain and so on all created positive characters with kindness and lofty sentiments, trying to correct bad practices in the society and devil minds in humanity. All of the films have touched college students and teachers, and analyzing the educational significance went viral at that time, getting a high response from the society. Each CCTV Touch China program will praise and choose Top Ten Touching China Figures, and everyone's story could shock the hearts of the people, showing traditional Chinese virtues and leading social morality. Those who are presented poor in substance and life in screen culture are in unceasing pursuit of spiritual world and advocating gracious spirit, showing honesty and good faith to audiences, and instruct college students to get outer beauty and kind heart, awakening the hopes for truth, kindness and beautification and leading them to set correct aesthetic value.

\section{B. Negative Effect}

Shock the mainstream political values in China, the USled west capitalist countries pursue cultural Hegemonism around the world, launching a white war in ideology, of which no doubt, Hollywood spearheads. Hollywood is an industrial system, the first in history, aimed at large-scale industrial production and ideology transmission, and it has not only got abundant profits in film markets around the world but also promoted its political ideology popular in other countries. Relying on top quality design and production, American films have attracted a great number of college student audiences, yet what hidden in well-designed stories are individualistic heroism, chosen people, American dreams and so on, which bring huge shocks to the mainstream political values that college students hold in China, causing a deviation in Chinese ideology. "Only the US can rescue the world" is a designated model for most Hollywood films, for example, the film Pacific Rim, released in summer 2013, earned 690 million yuan in China, describing a story where manned robots from around the world fight against huge monsters. Drivers from China and Russia are presented outrageous and also completely defeated in wars against monsters; ultimately American robots take the mission to rescue the world. Such films endeavor to whitewash American economy, technologies and life, excessively propagating individualistic heroism, no doubt, college students whose political values are not established are induced to get close to western political systems and ideology, which destabilize their correct understanding of socialist system superiority and collectivism, weakening the sense of national identity and self-confidence and severely destroying college students' political values to be formed. Inducing abnormal and untutored marriage values, marriage values refer to an overall views, opinions and attitudes over nature of love and marriage, foundation and relevant morality, which will instruct the value standards and evaluation of the people in spouse selection and marital life. Love is the best feeling of human being, and active love can promote the people to struggle yet bad one may cause the people to fall. Some college students are just getting rid of the heavy pressure from enrollment, urgent to taste what love is or have just completed their study before employment, facing the coming marriage. It is urgent to train college students in correct marriage values in colleges, which however is little involved in college education in the country, and many college students, are confused with love and marriage. Love is a permanent topic for human being, which is often based on in films. Due to the lack of standard education, most take films as textbooks, taking the stories related to instruct problems related to love and marriage that they encounter in real life, some improper understandings have severely distorted their marriage values, causing utilitarianism in professional values. Professional values refer to "reflection of life goal and attitude in job selection, 
i.e. the understanding and attitude of a person as well as his or her pursuit of professional goal and yearning". With the establishment of market-based mode "mutual selection, free job selection and compete for posts", the professional values of college students are more and more scientific and rational, yet some films which describe work life have brought negative influences to college students' employment and work. First, money-targeted job selection standard. The film Tiny Times describes some girl students' lives from late college to initial work, it is inundated with money worship values such as luxuries, top grade houses, ostentatious decoration and stylish clothes. Such films induce audiences' desires for cakes and ale, willing to pursue the luxury that cannot be reached after struggling with the rest of their lives. When selecting jobs, pay has become the first factor to be considered, no careful comparison and analysis is conducted on what they have learned and post requirements so as to select jobs to apply what they have learned according to ideals of their own. Nobody connects individual developments with contributions to the country and achieve individual ideal and value whiling struggling for the country.

\section{Measures to DeVelop Students' Values THROUGH PROPER SCREEN CULTURE}

\section{A. Strengthen Supervision and Management over Film and TV Media}

Audiences have no doubt about the information shown in films because of high trusting authorities, facing such situation, authorities which govern public resources shall hold it responsible to regulate and standardize public media, leading the media to go actively and healthily. With regard to the supervision and management on film media, first of ally, strictly regulate the film media markets and optimize to allocate resources through markets. There are still many problems related to the media markets, for which administrative measures and means are required to regulate to make it go well, creating a sound air of spiritual culture for college students. Authorities should correctly guide the screen culture to improve the ideological level of films production, promoting the screen culture to develop on a way helping the people to set correct ideals and values. Improve laws and regulations relative to film spread, and increase penalty on illegal producers, issuers and disseminators through laws. Nowadays, all countries stress lawmaking for media and heavily hit illegal conducts and crimes in film media.

\section{B. Promote Screen Culture Industrialization and Enhance Its International Competition}

Establish Chinese film industry mechanism as soon as possible, and form film production, issue and release modern enterprise system. With great markets, Chinese films can get developed, produce and expand, can Chinese culture, spirits and value become stronger on the basis of films, spreading around the world and keeping the energy and charm with Chinese characteristics in the screen culture around the world.

\section{Improve College Students' Self Discipline}

External factors play a role only by internal factors, and social mechanism for individual values formation works depending on psychological mechanism. Whether political economic policies, eastern and western cultures, mass media or values advocated by educations, if consistent with the pursuits of value individuals hold internally, they will be easy to be accepted and consolidated, otherwise, it will cause contradictions. Correct values have to form during the selfdevelopment and construction of individuals. Accordingly to cultivate scientific values for individuals cannot be separated from the efforts of individuals, and college students shall be improved in self education. Once the capability of selfeducation is formed, it will become an active part for selfeducation of individuals, turning from educational object to subject, enriching the moral environment they hold inside and becoming internal factors for educational acceptance, up to that moment, the negative factors that film contain cannot directly influence the students' values.

\section{CONCLUSION}

At last, facing the huge information shock caused by screen culture and status quo of multiple values, college students may be confused with the value selection, who need to carefully analyze, compare and identify all kinds of values shown in screen cultures, distinguish the scientific, correct and active values from stodgy, improper and negative values, making free and willing selection, and the results selected can not only meet requirements of leading socialist values, satisfying individuals, but also going well with the social development laws as well as individual features.

\section{REFERENCES}

[1] Mc Quail, Audience Analysis [M] Beijing: People's Publishing House, 2006

[2] Neil Postman, translated by Zhang Yan, Amusing Ourselves to Death The Disappearance of Childhood [M] Guilin: Guangxi Normal University Press, 2009:41.

[3] Joshua Meyrowitz, No Sense of Place: The Impact of Electronic Media on Social Behavior [M]. Beijing: Tsinghua University Press, 2002:28.

[4] Guo Qingguang, Journalism \& Communication [M].Beijing: China Renmin University Press, 1999:189.

[5] Long Yun, TV and Violence Empirical Study on Medium Cultivation in China [M]. Beijing: China Radio \& Television Publishing House, 2005.

[6] Qin Junxiang, Accept TVs \& Films Psychologically [M]. Beijing Communication University of China, 2006. 